Article

\title{
The Tandem Ring Opening/Ring Closing Metathesis Route to Oxaspirocycles: An Approach to Phelligridin G
}

\author{
Harold D. Cooper ${ }^{1,2}$ and Dennis L. Wright ${ }^{1,2, *}$ \\ 1 Department of Pharmaceutical Sciences, University of Connecticut, Storrs, CT 06269, USA; \\ E-Mail: Harold.cooper@uconn.edu \\ 2 Department of Chemistry, University of Connecticut, Storrs, CT 06269, USA \\ * Author to whom correspondence should be addressed; E-Mail: dennis.wright@uconn.edu; \\ Tel.: +1-860-486-9274; Fax: +1-860-486-6857.
}

Received: 4 December 2012; in revised form: 31 January 2013 / Accepted: 7 February 2013 / Published: 21 February 2013

\begin{abstract}
Phelligridin $G$ is an unusual natural product that contains an embedded spiro-fused furanone core. We have investigated two furan-based synthetic approaches towards the spirocyclic core structure of this natural product from readily available 2-phenylfurans. Although initial studies involving an oxidative cyclization were unsuccessful, we were ultimately able to access this key system through a sequential intermolecular furan Diels-Alder reaction followed by a metathesis-based reorganization. A related approach led to an expanded $\mathrm{C}$ ring to form spiro-fused pyran spirocycles.
\end{abstract}

Keywords: phelligridin G; Diels-Alder; spiroannulations; metathesis; 2-phenylfurans; natural products

\section{Introduction}

There are a variety of therapeutics in use today that are derived from natural products isolated from various plant, marine or microbial sources. There is increasing evidence from animal studies that regular administration of powdered medicinal mushrooms can produce anti-cancer effects, demonstrating both high antitumor activity and restriction of tumor metastasis [1]. One such family of medicinal fungi has been derived from the species Phellinus igniarius, a member of the Polyporaceae family. Phelligridins D, E and G (Figure 1) are interesting natural products isolated from the fruiting body of $P$. igniarius. The fruiting body of $P$. igniarius has been long used in its role as a Traditional 
Chinese Medicine for the treatment of fester, bellyache and bloody gonorrhea [2]. Phelligridin G displays significant antioxidant activity, inhibiting rat liver microsomal lipid peroxidation and also shows moderate selective cytotoxic activity against a human ovarian (A2780) and colon cancer cell line (HCT-8) [3]. Based on the potential of phelligridin $\mathrm{G}$ as an anti-cancer agent, along with its unique and synthetically challenging spirofused-furanone, we set out to develop a rapid and efficient synthetic route to the core domain of the natural product.

Figure 1. Structural Derivatives of Phellinus igniarius.
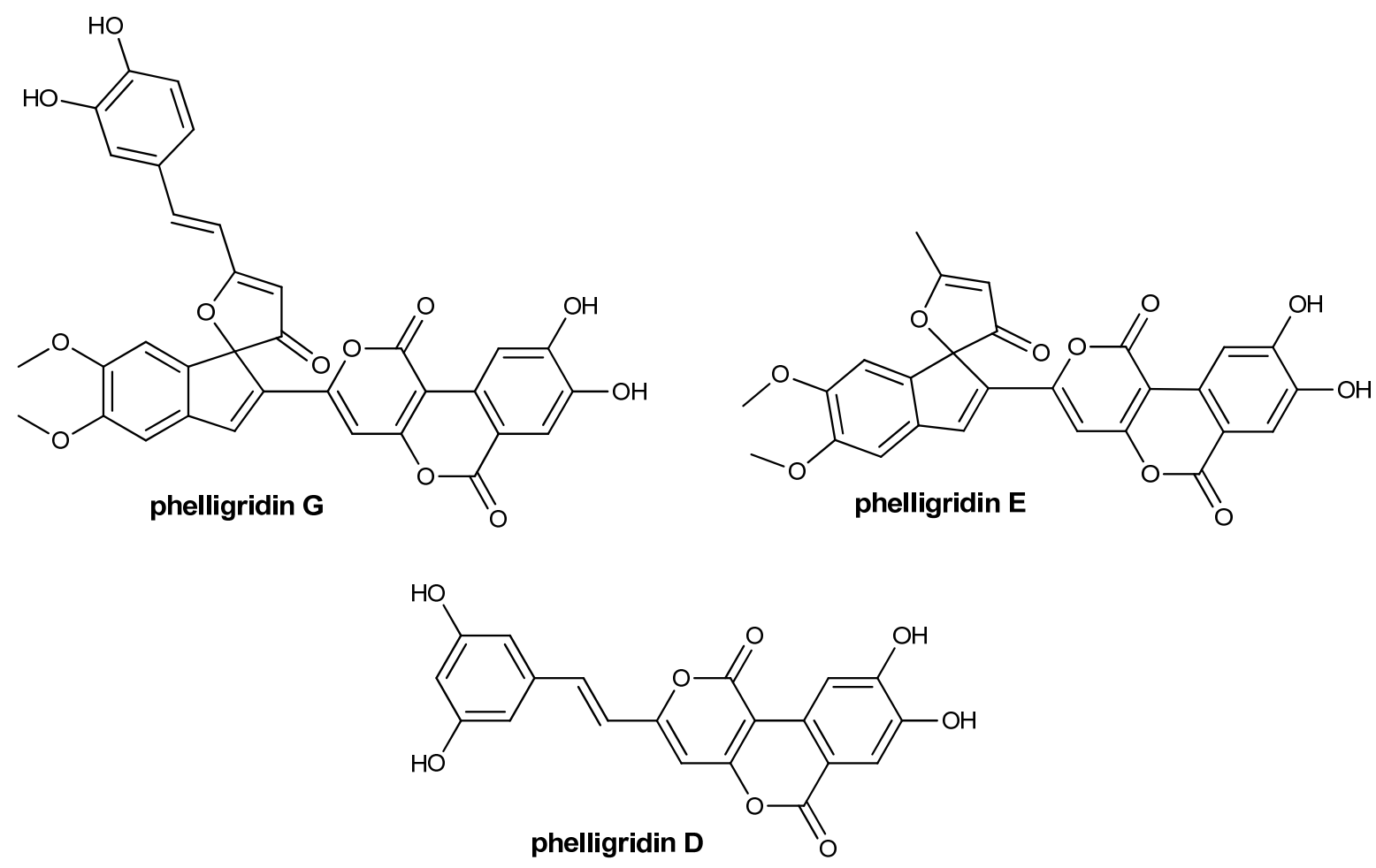

Our retrosynthetic analysis targeted the core domain 1, comprised of the $\mathrm{A}, \mathrm{B}$ and $\mathrm{C}$ rings characterized by the challenging 2-oxaspiro-[4.4]-octane unit (Scheme 1). We have been interested for some time in developing furan-based methodologies for the synthesis of polycyclic systems and felt that phelligridin $\mathrm{G}$ offered an excellent target to evaluate two strategies we have pursued. In one path, the presence of the spiro-fused 3-furanone makes it an attractive target for an electrochemical annulation strategy through oxidative cyclization of $\mathbf{2}$. We have worked extensively with furan-terminating electrochemical oxidative cyclizations and this method has been successful in the formation of 5-, 6-, and 7-membered carbocycles [4-7]. In a parallel approach to the anodic oxidation, a sequential furan Diels-Alder reaction to give $\mathbf{3}$, followed by a ring opening metathesis/ring closing metathesis (ROM/RCM) process could also deliver the target intermediate, a strategy we have recently employed in an approach to cyclopamine [8]. Exploration of both strategies would rely on the same two commercially available building blocks $\mathbf{4}$ and $\mathbf{5}$. 
Scheme 1. Retrosynthetic analysis of Phelligridin G.
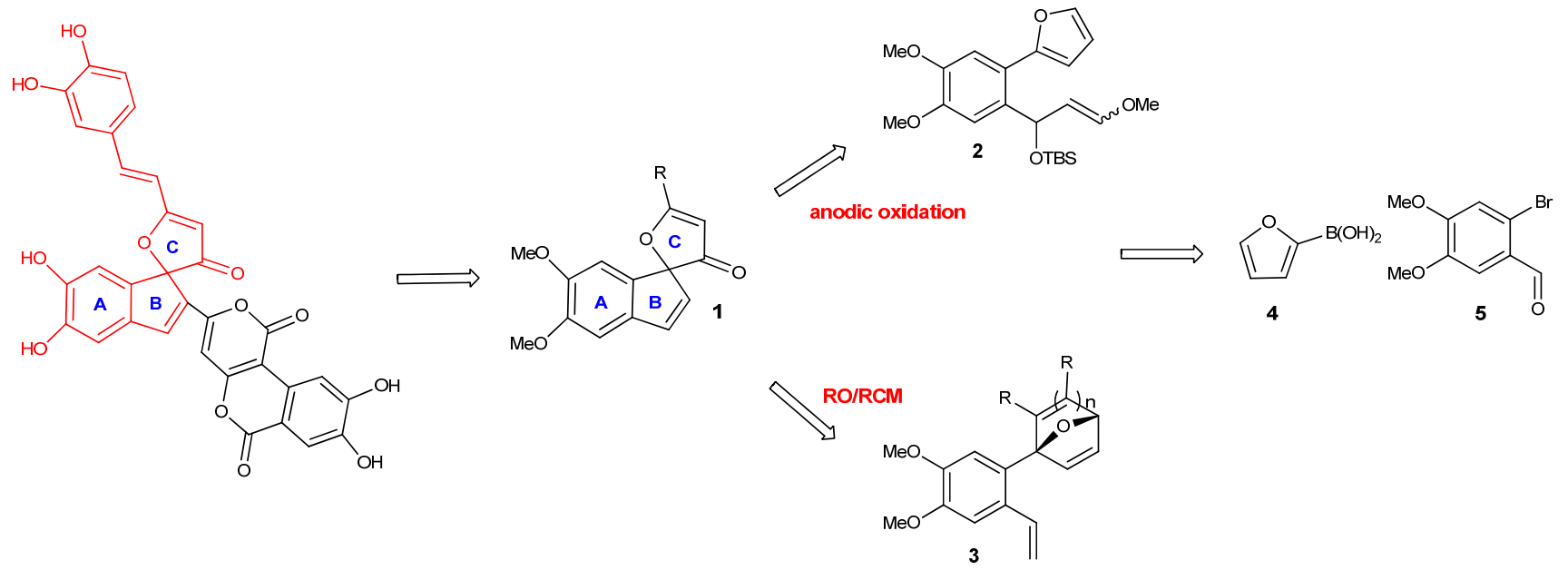

\section{Results and Discussion}

\subsection{Electrochemical Studies}

The commercially available starting materials 2-furanboronic acid (4) and 3,4-dimethoxybromobenzaldehyde (5) were joined through standard Suzuki cross-coupling with bis(triphenylphosphine)palladium(II) dichloride to produce the 2-phenylfuran derivative 6 in good yield (Scheme 2). The aldehyde was homologated with $t$-butyldimethylsilyl cyanide, followed by reduction of the nitrile group in the presence of DIBAL-H to give the protected $\alpha$-hydroxyaldehyde after hydrolysis with dilute sulfuric acid. The $\alpha, \beta$-unsaturated aldehyde underwent smooth Wittig olefination to deliver enol ether intermediate 7. Unfortunately, and despite earlier success with similar systems [9], all attempts to produce the spiro-fused product through anodic oxidation failed, producing only complex mixtures of products. Further oxidative studies were attempted using the traditional chemical oxidants cerium(IV)ammonium nitrate (CAN) [10] and tris(4-bromophenyl)aminium hexachloroantimonate (BAHA) [11] which are known to oxidize electron-rich olefins, but these also proved to be ineffective. We believe that the presence of additional groups with low oxidation potentials such as the dimethoxyphenyl ring and a 2-aryl furan leads to significant over oxidation and ultimate destruction of the starting material. The failure to detect any appreciable cyclized material prompted us to explore the alternative cycloaddition/metathesis approach to this class of compounds.

Scheme 2. Attempted oxidative cyclization to the spirocyclic core.

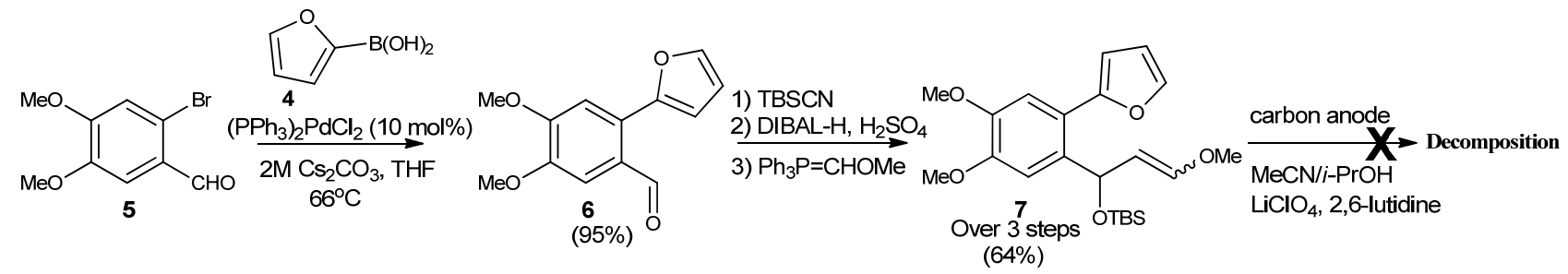




\subsection{Diels-Alder/Metathesis Studies}

The value of oxabicyclic building blocks for the preparation of five-membered heterocycles has been appreciated for some time [12-14]. Our synthesis of the spirocyclic core of phelligridin G would be achieved in four steps starting with the previously described furyl-benzaldehyde derivative 6 (Scheme 3). Olefination of the $\alpha, \beta$-unsaturated carbonyl with methyl triphenylphosphonium bromide in the presence of $n$-butyl lithium yielded styrylfuran 8. In order to obtain a suitable precursor for the metathesis-driven bond reorganization, thermal cycloaddition to the furan via standard Diels-Alder reaction was envisioned. Usually furan is a highly reactive diene, but in this system this reactivity became highly attenuated due to the presence of the aryl ring in the $\mathrm{C} 2$ position. It has been previously observed that 2-phenylfurans are poor dienes in Diels-Alder cycloadditions as a direct result of their high $\pi$-conjugation, which is destroyed upon formation of the cycloadduct, thus promoting rapid retro-Diels-Alder reaction [15]. We explored a series of structurally diverse dienophiles based upon accessibility and reactivity rates to form the cycloaddition products.

Scheme 3. Synthesis of ABC spiroannulated core via Domino ROM/RCM metathesis.

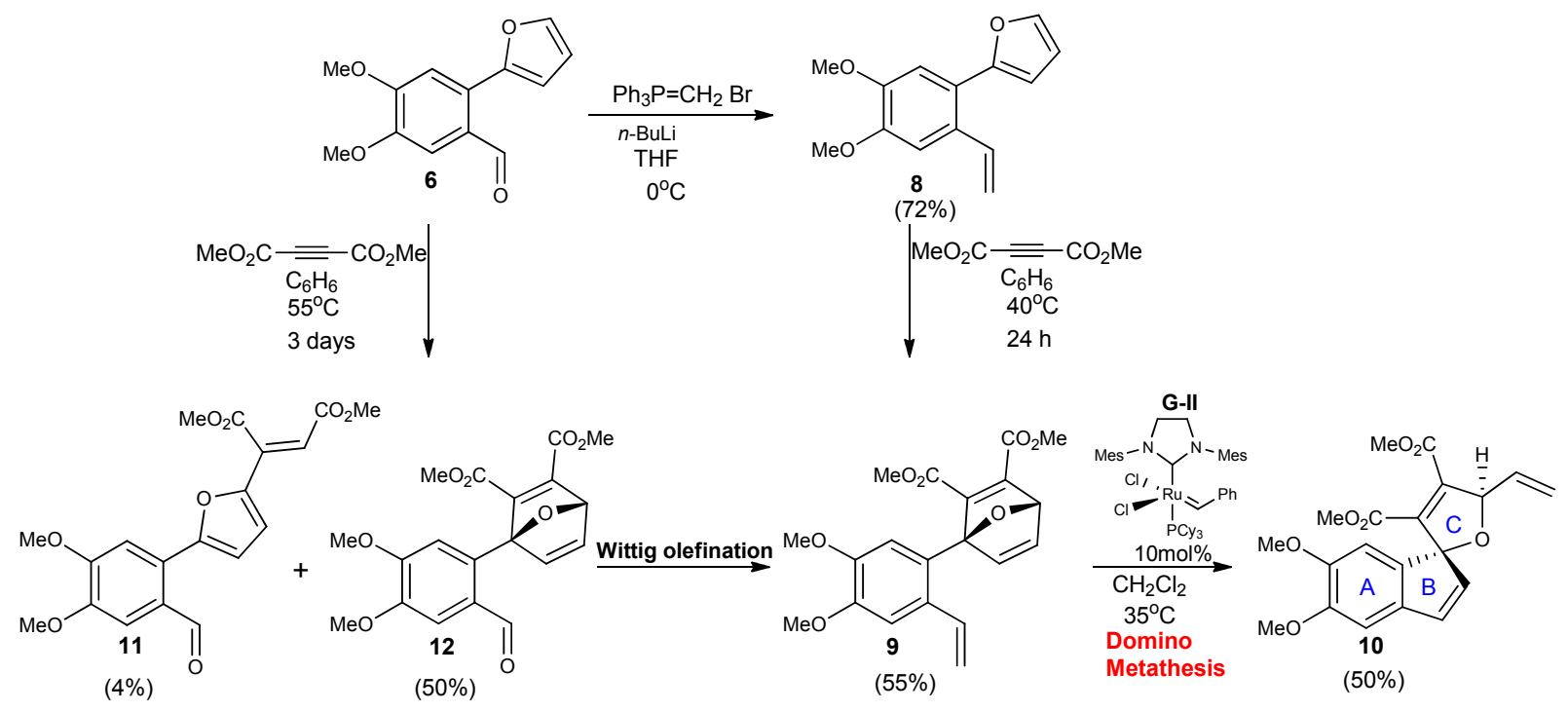

We found that the $\mathrm{sp}^{2}$-type dienophiles such as $n$-methylmaleimide, cyanovinyl acetate, dimethyl fumarate, and fumaryl chloride only returned unchanged starting materials after days of continuous heating. Using more reactive alkynes seemed promising as we had some success with treating substituted furan scaffolds with acetylenic dienophiles in previous studies [8]. However, with this 2-phenylfuran no oxabicyclic ether formation was observed at moderate temperatures with monofunctionalized alkynes such as tosyl acetylene or methyl propriolate. At higher temperatures, cycloaddition does occur, but this is followed by a spontaneous ring-opening/aromatization process to produce an undesired phenol. Pleasingly, use of a more deactivated alkyne, dimethyl acetylenedicarboxylate (DMAD), under mild thermal conditions $\left(\mathrm{rt} \rightarrow 40{ }^{\circ} \mathrm{C}\right)$ led to the desired adduct 9 in reasonable yield. We also examined the potential of aldehyde 6 to participate in the [4+2] cycloaddition. As expected, condensation of aldehyde 6 with DMAD required higher temperatures $\left(55^{\circ} \mathrm{C}\right)$ as well as longer reaction time, owing to the presence of the electron-withdrawing group which deactivates the furan ring system. Ultimately, this reaction did produce the adduct 12 in $\sim 50 \%$ isolated 
yield, which could be taken on to 9 by olefination. Furthermore, small amounts of Michael product 11 occurred as a byproduct. With the key oxabridged intermediate in hand, we were able to attempt the key metathesis reaction. The oxabicyclo adduct 9 undergoes a ring opening/ring closing (ROM/RCM) domino type metathesis using Grubbs $2^{\text {nd }}$ generation catalyst to form spiro compound $\mathbf{1 0}$ as a single diastereomer (as observed by ${ }^{1} \mathrm{H}$ and ${ }^{13} \mathrm{C}$-NMR) that contains the core structure of phelligridin $\mathrm{G}$. The release of ring-strain in the bridged bicyclic compound is an important driving force in these types of reactions and have been increasingly used to generate complex natural products $[8,16-19]$.

In our desire to expand this utility of this methodology, we looked at the highly reactive perhalogenated cyclopropenes as cycloaddition partners (Scheme 4). With the assistance of these compounds, we have been able to develop building blocks leading to the synthesis of several natural products [20,21]. It was felt that the cycloaddition of perhalocyclopropenes would be more efficient as the initial cycloadduct spontaneously rearranges to the ring-expanded system thus preventing the retroDiels-Alder reaction from taking place. Oxabicyclo[3.2.1] octane $\mathbf{1 4}$ was easily prepared in a one-pot sequence that involved heating 6 and tetrachlorocyclopropene (TCCP) 13 at $55^{\circ} \mathrm{C}$ for 4 days, followed by olefination to give $\mathbf{1 5}$ without benefit of further purification. Compound $\mathbf{8}$ under similar reaction conditions was much less reactive as the alkene seemed to hinder the cycloadduct formation with this particular dienophile.

Scheme 4. Expansion of the C-ring of the phelligridin G core to form the spiro-fused pyran moiety.
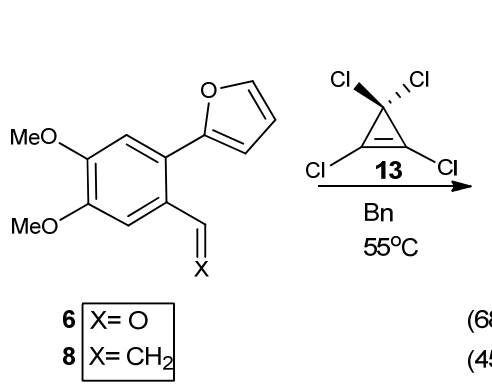

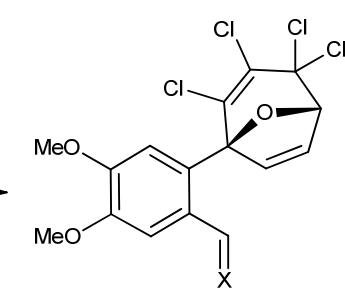

$(68 \%) 14 \mathrm{X}=\mathrm{O} \longrightarrow \mathrm{Ph}_{3} \mathrm{P}=\mathrm{CH}_{2} \mathrm{Br}$
$(45 \%) 15 \mathrm{X}=\mathrm{CH}_{2} \longleftarrow$
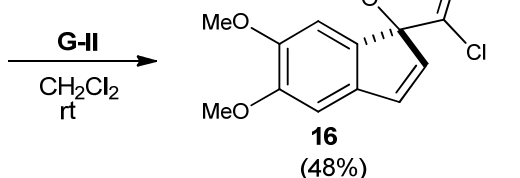

The strained ether-bridged seven-membered ring likely undergoes a ring opening of the endocyclic double bond followed by closure with the terminal olefin to form the B ring of the spiro-fused product. For oxabicyclo[3.2.1] octane 15, the GII catalyst was also optimal but heating of the mixture was unnecessary in this system and produce the highly functionalized spiro-pyran $\mathbf{1 6}$ in moderate overall yield.

\section{Experimental}

\section{General}

All reactions were carried out under an inert argon atmosphere with dry solvents under anhydrous conditions, unless otherwise noted. Commercial grade reagents and solvents were purchased and used without further purification except as indicated below. Hexanes, tetrahydrofuran (THF), diethyl ether $\left(\mathrm{Et}_{2} \mathrm{O}\right)$, and dichloromethane $\left(\mathrm{CH}_{2} \mathrm{Cl}_{2}\right)$ were used directly as obtained from a Baker Cycle-tainer ${ }^{\mathrm{TM}}$ system. Yields refer to chromatographically and spectroscopically ( $\left.{ }^{1} \mathrm{H}-\mathrm{NMR}\right)$ homogenous materials, unless otherwise stated. Reactions were monitored by thin layer chromatography (TLC) carried out on Whatman silica gel $60 \AA$ precoated plates using UV light as the visualizing agent and an acidic mixture 
of DNP or basic aqueous potassium permanganate $\left(\mathrm{KMnO}_{4}\right)$ and heat as developing agents. Flash chromatography was performed using Baker silica gel (60 $\AA$ particle size). NMR spectra were recorded on Bruker-500 and 400 instruments and calibrated using the residual undeuterated solvent signal as an internal reference $\left(\mathrm{CHCl}_{3}\right.$ at $\delta 7.26 \mathrm{ppm}$ for ${ }^{1} \mathrm{H}-\mathrm{NMR}, \delta 77.1 \mathrm{ppm}$ for ${ }^{13} \mathrm{C}$-NMR). The following abbreviations were used to explain the multiplicities: $\mathrm{s}=$ singlet, $\mathrm{d}=$ doublet, $\mathrm{t}=$ triplet, $\mathrm{q}=$ quartet, $\mathrm{m}=$ multiplet, $\mathrm{b}=$ broad. IR Spectra were recorded on Shimadzu FT-IR 8400 spectrometer. Melting points (m.p.) were uncorrected and measured with a Mel-Temp digital melting point apparatus. High resolution mass spectra (HRMS) were obtained from the University of Connecticut Mass Spectral Facility by using Direct Analysis in Real Time using an AccuTOF (JEOL) mass spectrometer.

2-Furan-2-yl-4,5-dimethoxybenzaldehyde (6). Commercially available 3,4-dimethoxybromobenzaldehyde 5 ( $0.5 \mathrm{~g}, 2.04 \mathrm{mmol})$ was added to an argon purged $25 \mathrm{~mL}$ flask. Anhydrous THF $(10 \mathrm{~mL})$ was added, followed by 2 -furanboronic acid (2 equiv.), and $\mathrm{PdCl}_{2}\left(\mathrm{PPh}_{3}\right)_{2}$ (0.1 mol equiv.). Once all the reagents were in solution, $2 \mathrm{M}$ aqueous solution of $\mathrm{Cs}_{2} \mathrm{CO}_{3}$ ( 3 mol equiv.) was added to the flask, which was immediately placed in a preheated oil bath and refluxed with vigorous stirring for 12-24 h. Once the reaction was deemed complete, it was cooled to room temperature, quenched with $\mathrm{H}_{2} \mathrm{O}$, and diluted with $\mathrm{Et}_{2} \mathrm{O}$. The aqueous layer was extracted with $\mathrm{Et}_{2} \mathrm{O}(3 \times 5 \mathrm{~mL})$ and the combined organic layers were washed with brine, dried over $\mathrm{Na}_{2} \mathrm{SO}_{4}$, and concentrated to give a crude yellow solid. The crude product was purified by column chromatography on silica gel (6:1 hexane/ethyl acetate) to yield $6(95 \%)$ as a solid. $\mathrm{R}_{f}=0.38 ; \mathrm{m} . \mathrm{p} .=102{ }^{\circ} \mathrm{C} ; \mathrm{IR}\left(\mathrm{KBr}, \mathrm{cm}^{-1}\right): v: 730,909,1280,2255$, $3012{ }^{1} \mathrm{H}-\mathrm{NMR}\left(400 \mathrm{MHz}, \mathrm{CDCl}_{3}\right): \delta=3.96-4.04(\mathrm{~m}, 6 \mathrm{H}), 6.58(\mathrm{~s}, 2 \mathrm{H}), 7.13(\mathrm{~s}, 1 \mathrm{H}), 7.54(\mathrm{~s}, 1 \mathrm{H})$, $7.62(\mathrm{~s}, 1 \mathrm{H}), 10.27(\mathrm{~s}, 1 \mathrm{H}) .{ }^{13} \mathrm{C}-\mathrm{NMR}\left(126 \mathrm{MHz}, \mathrm{CDCl}_{3}\right) \delta=190.58,154.46,153.48,150.43,149.04$, $143.47,128.85,126.67,115.40,111.76,110.38,108.83,77.44,77.12,76.80,65.76,56.00$; HRMS (DART) calcd. for $\mathrm{C}_{13} \mathrm{H}_{13} \mathrm{O}_{4}[\mathrm{M}+\mathrm{H}]^{+}$: 233.0814; found 233.0823 .

(tert-Butyldimethylsilanyloxy)-2-furan-2'-yl-4,5'-dimethoxyphenyl)acetonitrile. To a flame dried flask was added $t$-butyldimethylsilyl cyanide $(0.141 \mathrm{~g}, 1.0 \mathrm{mmol})$, potassium cyanide $(0.003 \mathrm{~g}, 0.05 \mathrm{mmol})$, and 18-crown-6 (0.053 g, $0.4 \mathrm{mmol})$ under an argon atmosphere. A solution of aldehyde $6(0.116 \mathrm{~g}$, $0.500 \mathrm{mmol})$ in dry methylene chloride $(5 \mathrm{~mL})$ was added dropwise over $30 \mathrm{~min}$ to the homogenous mixture. The reaction was stirred vigorously for $24 \mathrm{~h}$ and monitored by TLC. Upon reaction completion the solvent is removed in vacuo and the crude oily residue was purified by flash chromatography using $15 \%$ EtOAc in hexanes to obtain a pure yellow oil $(0.177 \mathrm{~g}$, 95\% yield). $\mathrm{R}_{f}=0.67$; IR $\left(\mathrm{KBr}, \mathrm{cm}^{-1}\right)$ v: 654, 735, 908, 2254, 2962, $3012{ }^{1} \mathrm{H}-\mathrm{NMR}\left(500 \mathrm{MHz}, \mathrm{CDCl}_{3}\right)$ : $\delta=0.02-0.12(\mathrm{~d}, J=50 \mathrm{~Hz}, 6 \mathrm{H}), 0.89(\mathrm{~s}, 9 \mathrm{H}), 3.93-3.95(\mathrm{~d}, J=10 \mathrm{~Hz}, 6 \mathrm{H}), 5.89(\mathrm{~s}, 1 \mathrm{H}), 6.53(\mathrm{~s}, 2 \mathrm{H})$, $7.02(\mathrm{~s}, 1 \mathrm{H}), 7.30(\mathrm{~s}, 1 \mathrm{H}), 7.55(\mathrm{~s}, 1 \mathrm{H}) .{ }^{13} \mathrm{C}-\mathrm{NMR}\left(126 \mathrm{MHz}, \mathrm{CDCl}_{3}\right) \delta=151.8,149.5,147.2,126.6$, 121.8, 119.7, 111.8, 110.9, 110.1, 108.9, 61.2, 56.2, 25.7, 18.3, -5.1; HRMS (DART) calcd. for $\mathrm{C}_{20} \mathrm{H}_{28}$ $\mathrm{NO}_{4} \mathrm{Si}[\mathrm{M}+\mathrm{H}]^{+}: 374.1788$; found 374.1776 .

(tert-Butyldimethylsilanyloxy)-2-furan-2'-yl- 4,5'-dimethoxyphenyl)acetaldehyde. Silyl cyanide (0.455 g, $1.22 \mathrm{mmol})$ was dissolved in dry toluene $(4 \mathrm{~mL})$ and cooled to $-78{ }^{\circ} \mathrm{C}$. DIBAL $(0.868 \mathrm{~g}, 6.1 \mathrm{mmol})$ was added dropwise to the flask and the mixture stirred $2 \mathrm{~h}$ at this temp. Once the imine is formed, the reaction was quenched with methanol $(2.1 \mathrm{~mL})$ and warmed up to $0{ }^{\circ} \mathrm{C}$. After $2 \mathrm{~h}, 1 \mathrm{~N} \mathrm{H}_{2} \mathrm{SO}_{4}(2 \mathrm{~mL})$ 
was added dropwise to the mixture while stirring for $1 \mathrm{~h}$ at this temperature. Diethyl ether was added to dilute the reaction and the aqueous layer was separated. The aqueous layer was extracted with ether $(3 \times 3 \mathrm{~mL})$ and the ethereal layer collected, washed with brine, dried over $\mathrm{Na}_{2} \mathrm{SO}_{4}$, and the solvent removed in vacuo. The crude oil was purified by flash chromatography using a 10\% EtOAc in hexanes solution to obtain a pure oil $(0.200 \mathrm{~g}, 44 \%$ yield $) . \mathrm{R}_{f}=0.49$; $\mathrm{IR}\left(\mathrm{KBr}, \mathrm{cm}^{-1}\right) v: 732,913,1735,2934$, 2959, $3012{ }^{1} \mathrm{H}-\mathrm{NMR}\left(500 \mathrm{MHz}, \mathrm{CDCl}_{3}\right.$ ): $\delta=-0.09-0.02$ (d, $\left.J=-35 \mathrm{~Hz}, 6 \mathrm{H}\right), 0.87$ (s, 9H), 3.91-3.92 $(\mathrm{d}, J=5 \mathrm{~Hz}, 6 \mathrm{H}), 5.50(\mathrm{~s}, 1 \mathrm{H}), 6.49-6.61(\mathrm{dd}, J=10,5 \mathrm{~Hz}, 2 \mathrm{H}), 7.07-7.09(\mathrm{~d}, J=10 \mathrm{~Hz}, 2 \mathrm{H}), 7.51$ (s, 1H). ${ }^{13} \mathrm{C}-\mathrm{NMR}\left(126 \mathrm{MHz}, \mathrm{CDCl}_{3}\right) \delta=198.9,152.3,149.3,148.9,142.4,127.2,122.8,111.5$, $111.2,110.5,108.9,76.2,56.0,25.7,25.7,18.3,-4.9$; HRMS (DART) calcd. for $\mathrm{C}_{20} \mathrm{H}_{29} \mathrm{O}_{5} \mathrm{Si}[\mathrm{M}+\mathrm{H}]^{+}$: 377.1784; found 377.1760 .

tert-Butyl-[1-(2-furan-2 'yl-4',5'-dimethoxyphenyl)-3-methoxyallyloxy]dimethylsilane (7). To a stirred solution of dry THF $(3 \mathrm{~mL})$ was added methoxymethyltriphenylphosphonium bromide $(0.36 \mathrm{~g}$, $0.105 \mathrm{mmol}$ ) under argon. The homogenous mixture was cooled to $0{ }^{\circ} \mathrm{C}$ followed by addition of $\mathrm{NaO} t$ - $\mathrm{Bu}$ base ( 2 eq.) in one portion. The red-orange suspension was stirred about $30 \mathrm{~min}$ as the color persisted under the above temp. A $0.20 \mathrm{mM}$ solution of 2-furyl benzaldehyde $(0.802 \mathrm{~g}, 3.45 \mathrm{mmol})$ in THF was slowly added, and the reaction was monitored by TLC at $0{ }^{\circ} \mathrm{C}$. The reaction was quenched with $\mathrm{H}_{2} \mathrm{O}$ $(2 \mathrm{~mL})$ and diluted with ether $(4 \mathrm{~mL})$. The aqueous layer was extracted with $\mathrm{Et}_{2} \mathrm{O}$, and the combined extracts were washed with $\mathrm{H}_{2} \mathrm{O}$ and brine, then dried over $\mathrm{Na}_{2} \mathrm{SO}_{4}$. Removal of all solvents was done in vacuo to yield crude an oily residue as $E / Z$ isomers of $7(0.020 \mathrm{~g}, 64 \%) . \mathrm{R}_{f}=0.33$; IR $\left(\mathrm{KBr}, \mathrm{cm}^{-1}\right)$ : v: 812, 1278, 1687, 2857, 3233; ${ }^{1} \mathrm{H}-\mathrm{NMR}\left(500 \mathrm{MHz}, \mathrm{CDCl}_{3}\right): \delta=-0.11-0.05(\mathrm{~d}, J=-30 \mathrm{~Hz}, 6 \mathrm{H})$, $0.86(\mathrm{~s}, 9 \mathrm{H}), 3.48(\mathrm{~s}, 1 \mathrm{H}), 3.91-3.92(\mathrm{~d}, J=5 \mathrm{~Hz}, 6 \mathrm{H}), 4.90-4.94(\mathrm{~m}, J=20 \mathrm{~Hz}, 1 \mathrm{H}), 5.59-5.60$ (d, $J=5 \mathrm{~Hz}, 1 \mathrm{H}), 6.29-6.32(\mathrm{~d}, J=15 \mathrm{~Hz}, 1 \mathrm{H}), 6.37-6.48(\mathrm{~m}, J=55 \mathrm{~Hz}, 2 \mathrm{H}), 6.97$ (s, 1H), 7.22 (s, 1H), 7.49 (s, 1H). ${ }^{13} \mathrm{C}-\mathrm{NMR}\left(126 \mathrm{MHz}, \mathrm{CDCl}_{3}\right) \delta=153.0,149.2,148.8,147.7,141.8,135.7,120.7$, 111.4, 110.9, 109.9, 108.1, 107.3, 69.1, 56.1, 56.0, 25.9, 18.4, -4.7, -4.7; HRMS (DART) calcd. for $\mathrm{C}_{22} \mathrm{H}_{33} \mathrm{O}_{5} \mathrm{Si}[\mathrm{M}+\mathrm{H}]^{+}: 405.2097$; not detected.

2-(4,4-Dimethoxy-2-vinylphenyl)furan (8). To a stirred solution of dry THF (36 mL) was added methyl triphenylphosphonium bromide $(1.52 \mathrm{~g}, 4.32 \mathrm{mmol})$ under argon. The homogenous mixture was cooled to $0{ }^{\circ} \mathrm{C}$ followed by dropwise addition of a $2.5 \mathrm{M}$ solution $n$-BuLi in hexanes (1.25 eq.). The red-orange suspension was stirred about $30 \mathrm{~min}$ as the color persisted under the above temp. A $0.53 \mathrm{mM}$ solution of 2-furylbenzaldehyde $(6,0.802 \mathrm{~g}, 3.45 \mathrm{mmol})$ in THF was slowly added, and the reaction was complete at $0{ }^{\circ} \mathrm{C}$ after $10-15$ mins. The reaction was quenched with sat. aq. $\mathrm{NH}_{4} \mathrm{Cl}(10 \mathrm{~mL})$ and diluted with EtOAc $(20 \mathrm{~mL})$. The aqueous layer was extracted with EtOAc, and the combined extracts were washed with $\mathrm{H}_{2} \mathrm{O}$ and brine and then dried over $\mathrm{Na}_{2} \mathrm{SO}_{4}$. Removal of all solvents was done in vacuo to yield a crude solid material, which was purified by silica gel column chromatography (hexane/EtOAc, $10: 1)$ to yield olefin 8 as a yellow oil $(0.568 \mathrm{~g}, 72 \%) . \mathrm{R}_{f}=0.43$; IR $\left(\mathrm{KBr}, \mathrm{cm}^{-1}\right): v$ : 730, 909, 1266, 2254, $3007{ }^{1} \mathrm{H}-\mathrm{NMR}\left(500 \mathrm{MHz}, \mathrm{CDCl}_{3}\right): \delta=3.93-3.95$ (d, 6H, $\left.J=3.3 \mathrm{~Hz}\right), 5.24-5.26$ $(\mathrm{dd}, J=5,5 \mathrm{~Hz}, 1 \mathrm{H}), 5.59-5.62(\mathrm{~d}, J=15 \mathrm{~Hz}, 1 \mathrm{H}), 6.42-6.49$ (d, $J=35 \mathrm{~Hz}, 2 \mathrm{H}), 7.99-7.05$ (m, $J=30 \mathrm{~Hz}$, $1 \mathrm{H}), 7.03$ (s, 1H), 7.12 (s, 1H), $7.48(\mathrm{~s}, 1 \mathrm{H}) .{ }^{13} \mathrm{C}-\mathrm{NMR}\left(126 \mathrm{MHz}, \mathrm{CDCl}_{3}\right) \delta=152.64,148.91,141.91$, 135.98, 128.73, 122.63, 114.14, 111.56, 110.39, 109.39, 56.16, 56.11; HRMS (DART) calcd. for $\mathrm{C}_{14} \mathrm{H}_{15} \mathrm{O}_{3}[\mathrm{M}+\mathrm{H}]^{+}: 231.1021$; found 231.1000 . 
1-(4',5'-Dimethoxy-2'vinylphenyl)-7-oxabicyclo[2.2.1] hepta-2,5diene-2,3-dicarboxylic acid dimethyl ester (9). Dimethoxybenzylfuran 8 (343 $\mathrm{mg}, 1.49 \mathrm{mmol}$ ) was added to a flame dried vial in benzene $(0.37 \mathrm{~mL})$ to make a $3 \mathrm{mM}$ solution, followed by addition of DMAD (233 $\mathrm{mg}, 1.64 \mathrm{mmol})$ at room temperature. The reaction stirred vigorously until everything was in solution, then placed in a preheated oil bath at $40{ }^{\circ} \mathrm{C}$. The reaction was monitored by TLC using a 30\% EtOAc in hexanes solution. Upon completion the solvents were removed in vacuo to afford a crude oil, which was purified by silica gel chromatography $\left(\mathrm{SiO}_{2}, 7 \mathrm{~g}, 25 \%\right.$ EtOAc in hexanes to yield cycloadduct 9 as an oil (0.264 g, 55\%). $\mathrm{R}_{f}=0.21$; IR $\left(\mathrm{KBr}, \mathrm{cm}^{-1}\right): v: 731,908,1268,2345,3016$; ${ }^{1} \mathrm{H}-\mathrm{NMR}(500 \mathrm{MHz}$, $\left.\mathrm{CDCl}_{3}\right): \delta=3.57(\mathrm{~s}, 3 \mathrm{H}), 3.74(\mathrm{~s}, 3 \mathrm{H}), 3.84-3.86(\mathrm{~d}, J=10 \mathrm{~Hz}, 6 \mathrm{H}), 5.14-5.16(\mathrm{~d}, J=10 \mathrm{~Hz}, 1 \mathrm{H})$, $5.50-5.54(\mathrm{~d}, J=20 \mathrm{~Hz}, 1 \mathrm{H}), 5.75(\mathrm{~s}, 1 \mathrm{H}), 6.92-7.02(\mathrm{dd}, J=15,15 \mathrm{~Hz}, 1 \mathrm{H}), 7.01-7.03(\mathrm{~d}, J=10 \mathrm{~Hz}$, 2H), 7.27-7.28 (dd, $J=5 \mathrm{~Hz}, 1 \mathrm{H}), 7.47-7.48(\mathrm{~d}, J=5 \mathrm{~Hz}, 1 \mathrm{H}) .{ }^{13} \mathrm{C}-\mathrm{NMR}\left(126 \mathrm{MHz}, \mathrm{CDCl}_{3}\right)$ $\delta=164.9,162.7,158.8,149.4,149.2,148.6,145.2,144.7,134.7,130.0,123.6,114.7,110.9,109.4$, 97.9, 83.5, 55.9, 52.4; HRMS (DART) calcd. for $\mathrm{C}_{20} \mathrm{H}_{21} \mathrm{O}_{7}[\mathrm{M}+\mathrm{H}]^{+}:$373.1287; found 373.1280.

4'5'Dimethoxyspiro[5-oxafuryl-2,3 di(methoxycarbonyl)-4-vinyl]-1,1'[1H]indene (10). To a solution of oxabicyclic ether $9(177 \mathrm{mg}, 0.475 \mathrm{mmol})$ in dry dichloromethane $(47.5 \mathrm{~mL})$ was added a solution of Grubbs 2nd generation catalyst G-II (40 mg, $0.0475 \mathrm{mmol})$ in $1 \mathrm{~mL} \mathrm{CH}_{2} \mathrm{Cl}_{2}$ at room temperature. The reaction was stirred vigorously at room temperature then placed into a preheated oil bath at $35{ }^{\circ} \mathrm{C}$. The reaction was monitored by ${ }^{1} \mathrm{H}-\mathrm{NMR}$. After $24 \mathrm{hrs}$ of heating, the reaction was removed from heat and concentrated to a crude brown oil. Purification of the residue by flash chromatography using $25 \%$ EtOAc in hexanes afforded pure spirocyclic compound $10(0.048 \mathrm{~g}, 50 \%) . \mathrm{R}_{f}=0.21 ; \mathrm{IR}\left(\mathrm{KBr}, \mathrm{cm}^{-1}\right): v$ : 732, 907, 1255, 2253, 2955; ${ }^{1} \mathrm{H}-\mathrm{NMR}\left(500 \mathrm{MHz}, \mathrm{CDCl}_{3}\right): \delta=3.56(\mathrm{~s}, 3 \mathrm{H}), 3.81(\mathrm{~s}, 3 \mathrm{H}), 3.87-3.89(\mathrm{~d}$, $J=10 \mathrm{~Hz}, 6 \mathrm{H}), 5.28-5.30(\mathrm{~d}, J=20 \mathrm{~Hz}, 1 \mathrm{H}), 5.48-5.51(\mathrm{~d}, J=15,1 \mathrm{H}), 5.76-5.78(\mathrm{~s}, 1 \mathrm{H}) 5.99-6.04$ (m, 1H), 6.16-6.17 (d, $J=5.5 \mathrm{~Hz}, 1 \mathrm{H}), 6.61-6.62(\mathrm{~d}, J=5.5 \mathrm{~Hz}, 1 \mathrm{H}), 6.76(\mathrm{~s}, 1 \mathrm{H}), 6.89(\mathrm{~s}, 1 \mathrm{H})$. ${ }^{13} \mathrm{C}-\mathrm{NMR}\left(126 \mathrm{MHz}, \mathrm{CDCl}_{3}\right) \delta=163.1,162.3,150.3,148.4,142.9,136.7,136.6,135.7,133.7,128.8$, 127.0, 118.1, 107.8, 105.8, 99.38 86.4, 56.5, 56.6, 52.6; HRMS (DART) calcd. for $\mathrm{C}_{20} \mathrm{H}_{21} \mathrm{O}_{7}[\mathrm{M}+\mathrm{H}]^{+}$: 373.1287; found 373.1283 .

1-(2'-Formyl-4',5'dimethoxyphenyl)-7-oxabicyclo[2.2.1] hepta-2,5-diene-2,3-dicarboxylic acid dimethyl ester (12). Dimethoxyfurylbenzaldehyde $6(343 \mathrm{mg}, 1.49 \mathrm{mmol})$ in benzene $(0.37 \mathrm{~mL})$ was added to a flame dried vial to make a $3 \mathrm{mM}$ solution, followed by addition of DMAD (233 $\mathrm{mg}, 1.64 \mathrm{mmol})$ at room temperature. The reaction was stirred vigorously until everything was in solution, then added to a preheated oil bath at $50{ }^{\circ} \mathrm{C}$. The reaction was monitored by TLC using a $30 \%$ EtOAc solution in hexanes as eluent. Upon completion the solvents were removed in vacuo to afford a crude oil, which was purified by silica gel chromatography $\left(\mathrm{SiO}_{2}, 7 \mathrm{~g}, 25 \%\right.$ EtOAc in hexanes) to yield cycloadduct 12 as an oil. Diastereomers were obtained, which could be separated via column chromatography $(0.202 \mathrm{~g}, 50 \%$ of desired product 12$) . \mathrm{R}_{f}=0.085 ; \mathrm{R}_{f}=0.17 ; \mathrm{m} . \mathrm{p} .=175{ }^{\circ} \mathrm{C} ; \mathrm{IR}\left(\mathrm{KBr}, \mathrm{cm}^{-1}\right): v: 730$, 912, 1291, 1684, 3024; ${ }^{1} \mathrm{H}$ NMR (500 MHz, $\left.\mathrm{CDCl}_{3}\right): \delta=3.63(\mathrm{~s}, 3 \mathrm{H}), 3.81(\mathrm{~s}, 3 \mathrm{H}), 3.97-3.98(\mathrm{~d}$, $J=5 \mathrm{~Hz}, 6 \mathrm{H}), 5.76(\mathrm{~s}, 1 \mathrm{H}), 7.21(\mathrm{~s}, 1 \mathrm{H}), 7.25(\mathrm{~s}, 2 \mathrm{H}), 7.30-7.33(\mathrm{dd}, J=5,5 \mathrm{~Hz}, 1 \mathrm{H}), 7.45(\mathrm{~s}, 1 \mathrm{H})$, $10.03(\mathrm{~s}, 1 \mathrm{H}) .{ }^{13} \mathrm{C}-\mathrm{NMR}\left(126 \mathrm{MHz}, \mathrm{CDCl}_{3}\right) \delta=190.9,164.1,162.7,156.8,153.5,148.9,148.3,144.9$, 143.3, 129.9, 126.9, 114.6, 110.3, 96.6, 82.6, 56.2, 56.1, 52.3, 52.2; HRMS (DART) calcd. for $\mathrm{C}_{19} \mathrm{H}_{18} \mathrm{O}_{8}:[\mathrm{M}+\mathrm{H}]^{+}: 375.1080$; found 375.1069. 
4',5'-Dimethoxy-2-(2,3,4,4-tetrachloro-8-oxabicyclo[3.2.1]octa-2,6-dien-1-yl-benzaldehyde

(14).

Dimethoxyfurylbenzaldehyde $6(0.237 \mathrm{mmol})$ was dissolved in benzene to make a $2.97 \mathrm{M}$ solution at room temperature, followed by addition of tetrachlorocyclopropene ( 1 eq.). The homogeneous mixture was stirred vigorously, heated to $55{ }^{\circ} \mathrm{C}$ and stirred for 3-4 days. The reaction was monitored by TLC using a 25\% EtOAc in hexanes solution. Upon completion the solvents were removed in vacuo to afford a crude solid, which was purified by flash chromatography $\left(\mathrm{SiO}_{2}, 9 \mathrm{~g}, 25 \%\right.$ EtOAc in hexanes) to yield a yellow solid of $14(0.42 \mathrm{~g}, 68 \%) . \mathrm{R}_{f}=0.67 ; \mathrm{m} . \mathrm{p} .=175{ }^{\circ} \mathrm{C} ; \mathrm{IR}\left(\mathrm{KBr}, \mathrm{cm}^{-1}\right): v: 733,907$, 1277, 1516, 2938; ${ }^{1} \mathrm{H}-\mathrm{NMR}\left(500 \mathrm{MHz}, \mathrm{CDCl}_{3}\right): \delta=3.98-4.07(\mathrm{~d}, J=43 \mathrm{~Hz}, 6 \mathrm{H}), 5.46(\mathrm{~s}, 1 \mathrm{H}), 7.00$ $(\mathrm{s}, 1 \mathrm{H}), 7.30(\mathrm{~s}, 1 \mathrm{H}), 7.59(\mathrm{~s}, 1 \mathrm{H}), 10.23(\mathrm{~s}, 1 \mathrm{H}) .{ }^{13} \mathrm{C}-\mathrm{NMR}\left(126 \mathrm{MHz}, \mathrm{CDCl}_{3}\right) \delta=190.1,153.0,150.2$, 144.7, 138.7, 129.4, 127.9, 122.5, 112.6, 110.3, 94.2, 82.6, 75.2, 64.1, 63.3, 56.3, 56.2; HRMS (DART) calcd. for $\mathrm{C}_{16} \mathrm{H}_{13} \mathrm{Cl}_{4} \mathrm{O}_{4}[\mathrm{M}+\mathrm{H}]^{+}$: 410.9540; found 410.9540 .

\section{2,3,4,4,Tetrachloro-1-(4',5'dimethoxy-2'-vinylphenyl-8-oxabicyclo[3.2.1]octa-2,6-diene}

Cyclo-adduct 14 (0.237 mmol) was olefinated as mentioned above to give crude compound 15 which was purified using flash chromatography on silica gel (hexane/EtOAc, 20:1) to yield a yellow solid (0.57 g, 45\%). $\mathrm{R}_{f}=0.71$; IR (KBr, cm $\left.{ }^{-1}\right): v: 731,908,2252,2941,3014 ;{ }^{1} \mathrm{H}-\mathrm{NMR}\left(500 \mathrm{MHz}, \mathrm{CDCl}_{3}\right)$ : $\delta=3.95-3.99(\mathrm{~d}, J=16 \mathrm{~Hz}, 6 \mathrm{H}), 5.18-5.21(\mathrm{~d}, J=12 \mathrm{~Hz}, 1 \mathrm{H}), 5.39(\mathrm{~s}, 1 \mathrm{H}), 5.54-5.57(\mathrm{~d}, J=12 \mathrm{~Hz}$, $1 \mathrm{H}), 6.88-7.00(\mathrm{dd}, J=4 \mathrm{~Hz}, \mathrm{dd}, J=8 \mathrm{~Hz}, 1 \mathrm{H}), 6.93$ (s, 1H), 6.96 (s, 1H), 7.09 (s, 1H), 7.19 (s, 1H). ${ }^{13} \mathrm{C}-\mathrm{NMR}\left(126 \mathrm{MHz}, \mathrm{CDCl}_{3}\right) \delta=150.3,148.4,145.2,137.3,135.1,132.7,120.8,115.0,113.5,110.0$, 95.6, 82.4, 75.5, 64.7, 63.6, 56.2, 56.1; HRMS (DART) calcd. for $\mathrm{C}_{17} \mathrm{H}_{15} \mathrm{Cl}_{4} \mathrm{O}_{3}[\mathrm{M}+\mathrm{H}]^{+}:$408.9747; found 408.9767 .

4'5'Dimethoxyspiro[6-oxapyrano-2,3,4,4 tetrachloro-5-vinyl]-1,1'[1H]indene (16). Purification of the crude residue 16 by flash chromatography using 25\% EtOAc in hexanes afforded pure spiro-fused pyran. Yield: $0.048 \mathrm{~g}(48 \%) . \mathrm{R}_{f}=0.30$; IR $\left(\mathrm{KBr}, \mathrm{cm}^{-1}\right): v: 733,912,2324,2861,2943$; ${ }^{1} \mathrm{H}-\mathrm{NMR}$ $\left(500 \mathrm{MHz}, \mathrm{CDCl}_{3}\right): \delta=3.90-3.91(\mathrm{~d}, J=5 \mathrm{~Hz}, 6 \mathrm{H}), 5.07-5.08(\mathrm{~d}, J=5 \mathrm{~Hz}, 1 \mathrm{H}), 5.45-5.47(\mathrm{~d}$, $J=10 \mathrm{~Hz}, 1 \mathrm{H}), 5.52(\mathrm{~s}, 1 \mathrm{H}) 6.12-6.13(\mathrm{~d}, J=5 \mathrm{~Hz}, 1 \mathrm{H}), 6.22-6.28(\mathrm{~m}, J=30 \mathrm{~Hz}, 1 \mathrm{H}), 6.59-6.60$ (d, $J=5 \mathrm{~Hz}, 1 \mathrm{H}), 6.81(\mathrm{~s}, 1 \mathrm{H}), 7.68(\mathrm{~s}, 1 \mathrm{H}) .{ }^{13} \mathrm{C}-\mathrm{NMR}\left(126 \mathrm{MHz}, \mathrm{CDCl}_{3}\right) \delta=150.9,148.5,144.9,137.8$, 137.3, 134.3, 132.6, 131.3, 124.9, 121.2, 111.8, 106.5, 84.0, 70.20, 59.53, 56.6, 56.4; HRMS (DART) calcd. for $\mathrm{C}_{17} \mathrm{H}_{15} \mathrm{Cl}_{4} \mathrm{O}_{3}[\mathrm{M}+\mathrm{H}]^{+}:$408.9747; found 408.9772 .

\section{Conclusions}

The highly oxygenated oxaspirocyclic core of phelligridins $G$ and $E$ presents an interesting synthetic challenge, while the potential anticancer and antioxidant properties of the molecules make them compelling targets for study. In this work, we investigated two potential furan-based routes to the oxaspiro core of these compounds. Initial attempts to affect an electrochemical oxidative cyclization were complicated by facile over-oxidation of the products. An alternative route involving a challenging Diels-Alder cycloaddition with a highly substituted 2-styrylfuran, followed by a tandem ring-opening/ring-closing (domino) metathesis reaction proved successful. It was also possible to extend this strategy to the higher homolog by using a formal [4+3] cycloaddition reaction with tetrachlorocyclopropene. Current efforts towards the synthesis of phelligridin G based on this strategy are ongoing. 


\section{Supplementary Materials}

Supplementary materials can be accessed at: http://www.mdpi.com/1420-3049/18/2/2438/s1.

\section{Acknowledgments}

We are grateful to the National Science Foundation (CHE-0616760) for generous support of this work.

\section{References}

1. Holden, P.P.; Mcguire, B.; Stoler, A.; Belman, A.; Pitts, J. Changes in Gap Junctional Intercellular Communication in Mouse Skin Carcinogenesis. Carcinogenesis 1997, 18, 15-21.

2. Jiangsu New Medical College: Dictionary of Chinese Traditional Medicines; Shanghai Science and Technology Publishing House; Shanghai, China, 1977; p. 1967.

3. Wang, Y.; Mo, S.-Y; Wang, S.-J.; Li, S.; Yang, Y.-C.; Shi, J.-G. A Unique Highly Oxygenated Pyrano[4,3-c][2]benzopyran-1,6-dione Derivative with Antioxidant and Cytotoxic Activities from the Fungas Phellinus igniarius. Org. Lett. 2005, 7, 1675-1678.

4. Whitehead, C.; Sessions, E.H.; Ghiviriga, I.; Wright, D.L. Two Step Electrochemical Annulation for the Assembly of Polycyclic Systems. Org. Lett. 2002, 4, 3763-3765.

5. Sperry, J.; Whitehead, C.; Ghiviriga, I.; Walczak, R.M.; Wright, D.L. Electrooxidative Coupling of Furans and Silyl Enol Ethers:Application to the Synthesis of Annulated Furans. J. Org. Chem. 2004, 69, 3726-3734.

6. Sperry, J.; Wright, D.L. The gem-Dialkyl Effect in Electron Transfer Reactions: Rapid Synthesis of Seven-Membered Rings through an Electrochemical Annulation. J. Am. Chem. 2005, 127, 8034-8035.

7. Sperry, J.; Wright, D.L. The Application of Cathodic and Anodic Oxidations in the Synthesis of Complex Molecules. Chem. Soc. Rev. 2006, 35, 605-621.

8. Oblak, E.Z.; Wright, D.L. Tandem Metathesis Reactions of Oxabicyclo[2.2.1]heptanes: Studies on the Spirocyclic Core of Cyclopamine. Org. Lett. 2011, 13, 2433-2435.

9. Sperry, J.; Ghiviriga, I.; Wright, D.L. Electrochemical annulations of five-membered rings through dearomatization of furans and thiophenes. Chem. Commun. 2006, 194-196.

10. Snider, B.; Kwon, T. Oxidative Cyclization of $\delta, \varepsilon-$ and $\varepsilon, \zeta$-Unsaturated Enol Silyl Ethers and Unsaturated Siloxycyclopropanes. J. Org. Chem. 1992, 57, 2399-2410.

11. Walter, R.I. Substituent Effects on the Properties of Stable Aromatic Free Radicals. The Criterion for Non-Hammett Behavior. J. Am. Chem. Soc. 1966, 88, 1923-1930.

12. Orugunty, R.S.; Wright, D.L.; Battiste, M.A.; Abboud, K.A. Silver-Promoted Reactions of Bicyclo[3.2.1] octadiene Derivatives. Org. Lett. 2002, 4, 1997-2000.

13. Weeresakare, G.M.; Liu, Z.; Rainier, J. Highly Regioselective Ring Opening/Cross-Metathesis Reactions of 2-Sulfonylnorbene Derivatives. Org. Lett. 2004, 6, 1625-1627.

14. Pelphrey, P.; Orugunty, R.S.; Helmich, R.J.; Battiste, M.A.; Wright, D.L. Halogenated Oxabicyclo[3.2.1] octadiene Building Blocks: Elaboration of the Dibromoenone. Eur. J. Org. Chem. 2005, 2005, 4296-4303. 
15. Bennes, R.; Philp, D.; Spencer, N.; Kariuki, B.M.; Harris, K.D. Recognition-Mediated Facilitation of a Disfavored Diels-Alder Reaction. Org. Lett. 1999, 1, 1087-1090.

16. Wright, D.L.; Usher, L.; Estrella-Jimenez, M. Unusual Influence of Substituents on Ring-Opening Metathesis Reactions. Org. Lett. 2001, 3, 4275-4277.

17. Hart, A.C.; Phillips, A.J. Total Synthesis of (+)-Cylindramine A. J. Am. Chem. Soc. 2006, 128, 1094-1095.

18. Liu, Z.; Rainier, J. Regioselective Ring-Opening/Cross-Metathesis Reactions of Norbene Derivatives with Electron Rich Olefins. Org. Lett. 2005, 7, 131-133.

19. Jackson, K.L.; Henderson, J.A.; Motoyoshi, H.;Phillips, A.J. A Total Synthesis of Norhalichondrin B. Angew. Chem. Int. Ed. 2009, 48, 2346-2350.

20. Oblak, E.Z; Wright, D.L. Highly Substituted Oxabicyclic Derivatives from Furan: Synthesis of (+/-)-Platensimycin. Org. Lett. 2011, 13, 2263-2265.

21. Oblak, E.Z.; Bolstad, E.S.; Ononye, S.N.; Priestley, N.D.; Hadden, M.K.; Wright, D.L. The furan route to tropolones: Probing the Antiproliferative Effects of $\beta$-thujaplicin Analogs. Org. Biomol. Chem. 2012, Accepted.

Sample Availability: Samples of the compounds 6, 9,10, 14, 16 are available from the authors.

(C) 2013 by the authors; licensee MDPI, Basel, Switzerland. This article is an open access article distributed under the terms and conditions of the Creative Commons Attribution license (http://creativecommons.org/licenses/by/3.0/). 